\title{
HUBUNGAN BULLYING DENGAN KETIDAKBERDAYAAN PADA REMAJA
}

\author{
Tantri Widyarti Utami ${ }^{1 *}$, Alma Fadilah ${ }^{1}$, Livana $\mathbf{P H}^{2}$ \\ ${ }^{1}$ Poltekkes Kemenkes Bandung, Program Studi Keperawatan Bogor \\ ${ }^{2}$ Sekolah Tinggi Ilmu Kesehatan Kendal \\ *tantri_wu@yahoo.com
}

\begin{abstract}
ABSTRAK
Bullying merupakan salah satu permasalahan yang terjadi pada remaja yang tidak hanya berampak terhadap harga diri saja tetapi juga terhadap pendidikan, kesejahteraan fisik dan mental.Tujuan penelitian adalah untuk mengetahui hubungan antara bullying dan ketidakberdayaan pada remaja Penelitian ini menggunakan desain penelitian cross sectional dengan metode simple random sampling yang melibatkan 231 siswa SMA. Instrument yang digunakan adalah instrument Revised Olweus Bully/Victim Questionairre (OBVQ), dan Learned Helplessness Scale. Sample menggunakan simple random sampling dengan kriteria inklusi remaja usia 15-17 tahun, berada ditempat saat pengambilan data. Analisis data menggunakan uji chi square. Hasil penelitian menunjukkan adanya hubungan antara bullying dan ketidakberdayaan pada remaja remaja ( $\mathrm{p}$ value $=0,000)$.
\end{abstract}

Kata kunci: Bullying, ketidakberdayaan, remaja.

\section{THE RELATIONSHIP BETWEEN BULLYING ANDHELPLESSNESS IN ADOLESCENT}

\begin{abstract}
Bullying is one of the problems that occur in adolescents that is not only affect to self-esteem but also on education, physical and mental health well-being. The aim of te study was to determine the relationship between bullying andhelplessness in adolescent. This study used a cross sectional study design with a simple random sampling method involving 231 high school students. the instrument used is Revised Olweus Bully/Victim Questionairre(OBVQ), and Learned Helplessness Scale. Sample technique used simple random sampling with the inclusion criteria of adolescents aged 15-17 years, and is there when taking data.Data analyis used the chi square test. Results shown there was an relationship between bullying and helplessness in adolescent ( $p$ value $=0.0001$ ).
\end{abstract}

Keywords: bullying, helplessness, adolescent

\section{PENDAHULUAN}

Remaja merupakan penduduk dalam rentang usia 10-18 tahun (Kemenkes, 2014). Masa remaja merupakan masa peralihan dari masa pubertas menuju masa dewasa, masa remaja ini dibagi menjadi 3 bagian yaitu remaja awal, remaja tengah dan remaja akhir (Pieter, 2010)..Masa ini ditandai oleh adanya perubahan fisik, emosi dan psikis.Beberapa perubahan psikis pada remaja antara lain suka mencari perhatian dan bertindak tanpa berpikir terlebih dahulu, dan mudah bereaksi bahkan agresif terhadapgangguan atau rangsangan luar yang mempengaruhinya (Sarry, 2017).Banyaknya perubahan yang terjadi pada remaja menimbulkan beberapa masalah dan perilaku penyimpangan.
Perilaku menyimpang yang terjadi pada remaja merupakan hasil dari proses sosialisasi yang tidak sempurna. Beberapa kesulitan atau bahaya yang mungkin dialami kaum remaja, yaitu : variasi kondisi kejiwaan (Terkadang terlihat pendiam, cemberut, tetapi pada saat yang lain terlihat sebaliknya, periang, berseriseri), penyalahgunaan obat bius, psikosis perilaku anti sosial, seperti suka mengganggu, berbohong, kejam menunjukkan perilaku agresif, dan bullying (Jatmika, 2010).

Bullying merupakan bentuk penganiayaan beraneka ragam, yang ditandai dengan kegiatan yang dilakukan berulang kali kepada seseorang terhadap agresi fisik atau emosional termasuk menggoda, menyebut nama, 
mengejek, mengancam, melecehkan, mengejek, mengaburkan, pengucilan sosial atau rumor (WHO, 2010). TypeBullying dibagi menjadi 4, yaitu bullying fisik (memukul, menendang, mencubit dan mendorong), bullyingverbal (pemanggilan nama yang tidak sesuai, penghinaan, ejekan, intimidasi atau pelecehan verbal), bullying sosial (berbohong atau menyebarkan rumor, gerakan wajah atau fisik negatif, tampak mengancam atau menghina), cyber bullying (perilaku intimidasi menggunakan tekhnologi digital, seperti komputer, smartphone, media sosial atau situs web) (National Centre Against Bullying, 2019). Dasar-dasar pelaku bullyingmelakukan perbuatan bullyingdikarenakan faktor karakteristik korban, sikap korban, tradisi/budaya bullying di sekolah, serta pelaku memiliki kemampuan empati yang rendah (Rachmah, 2014).

Dampak yang terjadi korban bullyingyaitu akan merasa tidak nyaman, takut, rendah diri, serta tidak berharga, penyesuaian sosial yang buruk, menarik diri dari pergaulan, prestasi akademik yang menurun, merasa tidak berdaya, dan putus asa bahkan keinginan untuk bunuh diri (Wiyani, 2012).Salah satu dampak dari bullying ialah ketidakberdayaan.

Ketidakberdayaan merupakan pengalaman hidup kurang pengendalian terhadap situasi, termasuk persepsi bahwa tindakan seseorang secara signifikan tidak akan mempengaruhi hasil (NANDA, 2018). Penyebab dari ketidakberdayaan yang dipelajari dapat dikaitkan secara internal, eksternal atau keduanya, untuk individu atau kelompok sosial. Hal ini dapat mengakibatkan bentuk baru pengucilan yang mencegah perkembangan pribadi yang positif (Rehulina, Prayogo, 2014).

Perasaan ketidakberdayaan dapat mengurangi rasa percaya diri, sehingga berdampak negatif terhadap kualitas hidup seperti perubahan pola tidur, perasaan cemas, dan depresi. Penurunan kualitas hidup dapat mempengaruhi keadaan psikologis, gangguan dalam berpikir, serta gangguan dalam hubungan sosial.. Kondisi tersebut juga dapat menurunkan citra diri, mengganggu kemampuan seseorang untuk berpartisipasi dalam kegiatan sosial dan rekreasi, mempengaruhi kesejahteraan ,dan mengurangi rasa percaya diri.

Ketidakberdayaanharus diatasi karena mempengaruhi aktivitas $\mathrm{p}$ sehari-hari, ketergantungan akan kebutuhan sehari-hari serta tidak berpartisipasi dalam perawatan atau pengambilan keputusan pada saat diberikan kesempatan (Febriyani \& Darlina, 2017). Penelitian ini bertujuan untuk untuk mengetahui hubungan antara bullying dan ketidakberdayaan pada remaja melalui penelitian kuantitatif.

\section{METODE}

Penelitian ini merupakan penelitian jenis kuantitatif bersifat deskriptif korelatif dengan meng-gunakan pendekatan cross sectional, Proses pengukuran variabel independen dan dependen hanya dilakukan satu kali, setelah itu tidak dilakukan tindak lanjut.Sampel penelitian adalah 231siswa/siswi SMA di Bogor.Teknik pengambilan sampel yang digunakan peneliti yaitu simple random sampling yaitu teknik pengambilan sampel secara acak sederhana. Kriteria inklusi sampel penelitian yaitu siswa/siswi usia 15-17 tahun, berada di kelas saat pengambilan data dan bersedia menjadi responden.

Pengambilan data dilakukan dengan menggunakan tiga kuesioner. Kuesioner pertama berisi tentang data demografi, kuesioner kedua merupakan kuesioner bullyingmenggunakan instrument Revised Olweus Bully/Victim Questionairre(OBVQ), terdiri dari 14 item dengan skor $\geq 22$ mengalamibullying, dan kusioner ketigatentangketidakberdayaan menggunakan Learned Helplessness Scale terdiri dari 20 item dengan skor $\geq 33$ mengalami ketidakberdayaan

Data diolah dan diproses menggunakan sistem program komputer. Data dianalisis secara univariat dan bivariat dengan uji proporsi pada setiap variabel penelitian, meliputi karakteristik responden, perilaku bullying danketidakberdayaan. Uji chi square dengan kemaknaan $\mathrm{p}<$ 0,05digunakan untuk mengetahui hubungan antara bullying dan ketidakberdayaan. 
HASIL

Karakteristik responden dalam penelitian ini disajikan pada Tabel 1 berikut ini.

Tabel 1 Karakteristik Remaja

\begin{tabular}{|c|c|c|c|}
\hline Karakteristik & Sub karakteristik & $\mathrm{N}$ & $\%$ \\
\hline \multirow[t]{2}{*}{ Jenis kelamin } & Laki-laki & 72 & 31,2 \\
\hline & Perempuan & 159 & 68,8 \\
\hline \multirow[t]{2}{*}{ Kepribadian } & Ekstrovet & 147 & 63,6 \\
\hline & Introvet & 84 & 36,4 \\
\hline \multirow[t]{2}{*}{ Cara mengatasi masalah } & Memendam masalah & 132 & 57,1 \\
\hline & Menceritakan pada orang lain & 99 & 42,9 \\
\hline \multirow{3}{*}{ Jumlah sahabat } & 1 orang & 5 & 2,2 \\
\hline & $2-5$ orang & 51 & 22,1 \\
\hline & $\geq 5$ orang & 175 & 75,8 \\
\hline \multirow[t]{6}{*}{ Orang terdekat } & Orang tua & 141 & 61,9 \\
\hline & Adik/Kakak & 19 & 8,2 \\
\hline & Guru & 6 & 2,6 \\
\hline & Teman & 29 & 12,6 \\
\hline & Tidak ada & 1 & 0,4 \\
\hline & Lainnya & 33 & 14,3 \\
\hline
\end{tabular}

Tabel 2.

Bullying pada remaja $(\mathrm{n}=231)$

\begin{tabular}{lccc}
\hline & Variabel & $\mathrm{f}$ & $\%$ \\
\hline Bukan korban bullying & 100 & 43,3 \\
Korban Bullying & 131 & 56,7 \\
\hline
\end{tabular}

Tabel 2 menunjukkan ada sebanyak 131 orang remaja $(56,7 \%)$ menjadi korban bullying dan sebanyak 100 remaja $(43,3 \%)$ bukan korban bullying.

Tabel 3.

Ketidakberdayaan pada remaja $(\mathrm{n}=231)$

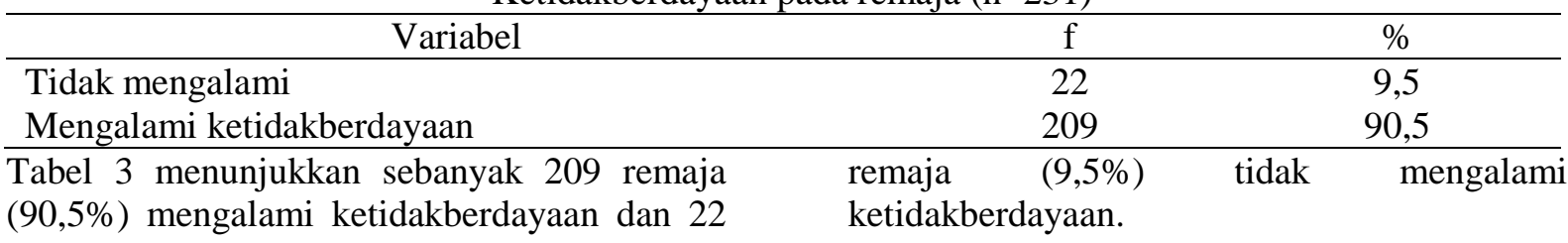

Tabel 4.

Hubungan hubungan bullying dan ketidaberdayaan pada remaja $(\mathrm{n}=22)$

\begin{tabular}{|c|c|c|c|c|c|}
\hline \multirow{3}{*}{ Bullying } & \multicolumn{4}{|c|}{ Ketidakberdayaan } & \multirow[t]{3}{*}{$\mathrm{P}$ value } \\
\hline & \multicolumn{2}{|c|}{ Mengalami } & \multicolumn{2}{|c|}{ Tidak mengalami } & \\
\hline & $\mathrm{f}$ & $\%$ & $\mathrm{f}$ & $\%$ & \\
\hline Bukan korban bullying & 21 & 21 & 79 & 79 & 0,000 \\
\hline Korban bullying & 1 & 0,8 & 130 & 99,2 & \\
\hline
\end{tabular}

Tabel 4 menunjukkan ada hubungan bullying dan ketidakberdayaan pada remaja ( $\mathrm{p}$ value $=$ $0,000)$.

\section{PEMBAHASAN}

Hasil penelitian ini menunjukan karakteristik remaja terbanyak adalah berjenis kelamin perempuan sebanyak $(68,8 \%)$, Hal ini sesuai dengan penelitian Silva, dkk (2013) 
menemukan adanya hubungan yang signifikan antara jenis kelamin dengan perilaku dan korbanbullying di mana anak laki-laki beresiko 9,84 kali lebih tinggi untuk melakukanbullying, dan 7,25 kali lebih tinggi perempuan sebagai korban bullying.

Pada penelitian ini juga remajasebanyak $(63,6 \%)$ memiliki kepribadian ekstrovert. sejalan dengan penelitian lain bahwa korban bullying tidak hanya mereka yang mempunyai kepribadian tertutup dan pasif dari dunia luar, tetapi juga mereka dengan kepribadian yang terbuka aktif juga menjadi korban bullying.(Wiyani, 2012). Orang yang extrovert sangat berbahaya bagi individu, apabila ikatan dengan dunia luar terlampau kuat, sehingga ia tenggelam dalam dunia objektif, kehilangan dirinya, atau asing terhadap dunia subjektifnya sendiri.

Cara mengatasi masalah pada remaja pada penelitian ini sebanyak $(57,1 \%)$ memendam masalahnya sendiri. Hal ini sejalan dengan penelitian Djuwita (2019) yang menyatakan bahwa korban bully tidak berani menceritakan masalahnya dengan oranglain karena malu mengakui keadaannya.

Jumlah sahabat pada remaja pada penelitian ini sebanyak $(75,8 \%)$ memiliki jumlah sahabat $\geq 5$ orang. Hal ini sejalan dengan penelitian Hidayat (2014) hasil penelitian menunjukkan bahwa faktor sosial yang mempengaruhi kejadian korban bullying adalah faktor teman sebaya, faktor media dan faktor sekolah.

Kedekatan remaja pada orang tua pada penelitian ini menunjukkan sebanyak $(61,9 \%)$ remaja menjadikan orang tua sebagai orang terdekat. Berdasarkan penelitian ini didapatkan faktor keluarga tidak mempengaruhi seseorang menjadi korban bullying.Penelitian lainmenunjukkan jika remaja sudah dekat dengan orangtua namun masih menjadi korban bullyingbisa dikarenakan kesibukan atau banyaknya masalah yang dihadapi orang tua, sehingga perhatian terhadap anaknya menjadi berkurang dan menyebabkan komunikasi orang tua dan anak menjadi sedikit terhambat pula.(Alex,2010). Hasil Penelitian ini menunjukan bahwa sebanyak $(56,7 \%)$ remaja menjadi korban bullying.Dikarenakan remaja pada masa ini sering menjadi terlalu percaya diri (over confidence) dan ini bersama-sama dengan emosinya yang biasanya meningkat, mengakibatkan sulit menerima nasihat dan pengarahan orangtua, lebih mudah dipengaruhi oleh teman-temannya daripada ketika mereka masih kanak-kanak. Ini berarti bahwa pengaruh orangtua semakin lemah (Jatmika,2010).Hal ini yang menyebabkan maraknya perilaku bullying dikalangan remaja.Selain itu faktor-faktor yang menyebabkan terjadinya bullying, terdapat faktor internal dan faktor eksternal. Faktor internal, yaitu : jenis kelamin, kepribadian individu, dan kepercayaan diri, sedangkan faktor eksternal, yaitu iklim sekolah, dan peranan kelompok atau teman sebaya(Putri, dkk, 2015).

Remaja yang menjadi korban bullying pada penelitian ini didapatkan sebanyak 56,7\%. Hal ini sesuai dengan penelitian Kejadian bullying di Indonesia antar remaja Kota Yogyakarta, penelitan dilakukan oleh Poeh, RA di tahun 2014, hasil survei yang dilakukan pada bulan Juli sampai dengan Agustus 2014 kepada 739 siswa SMAN di Kota Yogyakarta menunjukkan bahwa 396 siswa (54\%) mengaku pernah melihat kejadian bullyingdi lingkungan sekolah dan 100 siswa (13\%) merasa pernah mengalami bullying. Di Bogor kasus bullyingmencapai $40 \%$ pelajar di Kota Bogor, korban bullying masih berusia sekolah dasar, sekolah menengah pertama, dan sekolah menengah atas. Bullyingsering terjadi ketika seorang anak mempunyai kekurangan, baik secara fisik maupun mental.(Junior Chamber International, 2016).

Ketidakberdayaan pada remaja dalam penelitian ini dialami sebanyak $90,5 \%$ remaja.. Ketidakberdayaan merupakan pengalaman langsung dari kurangnya control atas suatu situasi, termasuk persepsi bahwa tindakan seseorang tidak secara signifikan mempengaruhi hasil (Carpenito- Moyet, 2013).Ketidakberdayaan dapat menurunkan rasa percaya diri, sehingga berdampak negatif terhadap kualitas hidup seperti perubahan pola tidur, perasan cemas, dan depresi. Penurunan kualitas hidup mempengaruhi keadaan psikologis, gangguan dalam berpikir, serta gangguan dalam hubungan sosial.(Febriyani \& Darlina, 2017).

Hubungan bullying dan ketidakberdayaan pada penelitian ini menunjukkan hubungan yang 
significant. Hal ini sesuai dengan penelitian oleh Wiyani (2012) bullying akan menimbulkan dampak di mana korban akan merasa tidak nyaman, takut, rendah diri, serta tidak berharga, penyesuaian sosial yang buruk, menarik diri dari pergaulan, prestasi akademik yang menurun, merasa tidak berdaya, dan putus asa bahkan keinginan untuk bunuh diri. Penelitian Khasanah, dkk (2017) menunjukan sebanyak $8,3 \%$ dari total remaja yang mengalami tindakan bullying, memiliki skema beliefs yang negatif dan sering mengalami ketidakberdayaan dalam kehidupan sehariharinya.

Remaja korbanbullying, akan mengalami kemunculan pikiran-pikiran negatif yang bersifat otomatis. Sebab, stimulus yang diterima dari tindakan bullying, akan membuat asosiasi negatif semakin kuat pada remaja. Hal ini membuat remaja mengembangkan sebuah skema bahwa dunia tidak aman dan sangat berbahaya. Munculah konsep ketidakberdayaan dan kemudian mengontrol sebagian besar kehidupan mereka dan membuat sebuah kekhawatiran muncul secara berlebihan. (Wang, 2011)

Dampak dari ketidakpercayaan remaja bahwa dunia tidak aman , remja gagal membantuk jati diri yang kokoh, mereka justru membentuk sebuah konsep ketidakberdayaan. Misalnya, menghindari atau melarikan diri dari masalah, baik itu masalah besar atau kecil, karena merasa tidak berdaya menghadapi kondisi tersebut

Peranan penting tenaga kesehatan, guru dan keluarga untuk mengurangi kemungkinan atau pencegahan agar tidak menjadi sasaran tindakan bullying. Pertama, bantulah remaja menumbuhkan self-esteem (harga diri) yang baik. Remaja ber- self-esteem baik akan bersikap dan berfikir positif, menghargai dirinya sendiri, menghargai orang lain, percaya diri, optimis dan berani mengatakan haknya.Kedua, mempunyai banyak teman. Bergabung dengan grup berkegiatan positif atau berteman dengan siswa yang sendirian. Ketiga, kembangkan keterampilan sosial untuk menghadapi bullying, baik sebagai sasaran atau sebagai saksi, dan bagaimana mencari bantuan jika mendapat perlakuan bullying.

Upaya yang dapat dilakukan untuk mengurangi ketidakberdayaan terhadap remaja korban bullying ialah mencoba menghilangkan pikiran-pikiran negatif dengan cara yang pertama, yaitu meningkatkan harga diri, tindakan yang dapat dilakukan adalah dengan mengkaji aspek positif apa yang dimilikinya, beri pujian yang realistis, dan hindarkan memberi penilaian yang negatif, kedua dengan cara menentukan tujuan realistis yang dapat dicapai dapat menerima diri, mempercayai diri sendiri dan orang lain bahwa ia membutuhkan bantuan orang lain, serta meningkatkan motivasi hidup.

\section{SIMPULAN}

Mayoritas remaja menjadi korban bullying $(56,7 \%)$ dan mayoritas mengalami ketidakberdayaan $\quad(90,5 \%)$. Terdapat hubungan bullying dan ketidakberdayaan pada remaja.

\section{DAFTAR PUSTAKA}

Alex, Sobur. (2010). Psikologi Umum. Bandung: Pustaka Setia.

Carpenito-Moyet,\& Lynda Juall. 2013. Nursing Diagnosis : Application to Clinical Practice. Philadelphia : Wolters Kluwer

Dhamayanti, M. \& Asmara, A. 2017.Remaja : Kesehatan dan Permasalahannya. Jakarta : Ikatan Dokter Anak Indonesia

Febriyani, P \& Darliana, D.2017.Perasaan Ketidakberdayaan Dengan Kualitas Hidup Pasien Ulkus.. Tersedia pada :http://www.jurnal.unsyiah.ac.id/INJ/arti cle/viewFile/8707/7029. 8(1) : 52-57. Diperoleh 06 Februari 2019.

Hidayat \& Namira. 2014. Analisis Hubungan Faktor Sosial Terhadap Kejadian Korban Bullying Di Sma Negeri Z Singaraja. Skripsi. Universitas Muhammadiyah Malang

Jatmika, Sidik. 2010. Genk Remaja, Anak Haram Sejarah ataukah Korban Globalisasi?.Yogyakarta : Kanisius

Junior Chamber International. 2016. Kasus Bullying di Kota Bogor. Tersedia pada :https://www.jointcommissioninternatio nal.org/. Diperoleh 03 Februari 2019.

Khasanah, dkk,. 2017. Gambaran Negative Automatic Thoughts pada Remaja Korban Bullyingdi Sekolah Menengah Pertama Kota Bandung. http://journal.uinsgd.ac.id/index.php/psy larticle/view/1698. 4(2). Diperoleh 05 Mei 2019. 
National Centre Againstbullying. 2019. Tersedia pada :. https://www.ncab.org.au/bullyingadvice/bullying-for-parents/types-ofbullying/\#. Diperoleh 02 Februari 2019

Pieter, H, Z., \& Lubis, N, L. 2010. Pengantar Psikologi dalam Keperawatan. Jakarta: Prenada Media Group

Poeh, R, A.. 2014. Program "Rembug Sahabat” Bagi Fasilitator Sebaya Dalam Pencegahan Bullying. (Tesis). Universitas Gajah Mada

Putri, dkk. 2015. Faktor-Faktor yang Berhubungan dengan Perilaku bullying pada Remaja. (Jurnal). Tersedia pada: https://media.neliti.com/media/publicati ons/187389-ID-faktorfaktor-yang-

berhubungan-dengan-per.pdf. 2(2) : 1149 - 1159. Diperoleh 07 Februari 2019.

Rachmah, D, N,. 2014. Empati pada Pelaku Bullying. Tersedia pada https://media.neliti.com/media/publicati ons/195880-ID-empati-pada-pelaku-

bullying.pdf\#page $=3 \&$ zoom $=$ auto, 107,381. 1(2): 51-58. Diperoleh 03 Februari 2019.

Rehulina, M. Prayogo,D. 2014. Hubungan antara Adversity dan Ketidakberdayaan yang Dipelajari pada Anak yang Berhadapan dengan Hukum (ABH) di Rumah Tahanan Surabaya.Tersedia pada

http://journal.unair.ac.id/downloadfullpapers-jpio4b9e98c0cf2full.pdf. 3(2): 108-116. Diperoleh 03 Februari 2019.

Sarry, Y, N, E,.2017. Perkembangan Kognitif dan Emosi Psikologi Masa Remaja Awal.Tersedia pada :ojshafshawaty.ac.id/index.php/jpengma s/article/download/1/2. 1(1): 6-12 Diperoleh 02 Februari 2019.

Sharma, S, A,. 2015. Learned Helplessness among Adolescent (Male \& Female) Students of Private and Government Schools.. Tersedia pada :http://www.iosrjournals.org/iosrjestft/papers/SSSSMHB/Volume6/01.PAPER\%2057.pdf. 1(6): 1-6. Diperoleh 04 Februari 2019.

Silva, M.A.I.S., Pereira, B., Mendoca, D., Nunes, B., Oliveira, W.A. (2013). The Involvement of Girls and Boys with
Bullying: An Analysis of Gender Differences.:

https://www.ncbi.nlm.nih.gov/pubmed/2 4317387. 10: 6820-6831. Diperoleh 05 Mei 2019.

WHO. 2010. Prevention of bullying-related morbidity and mortality: a call for public health policies. :https://www.who.int/bulletin/v olumes/88/6/10-077123/en/. Diperoleh 02 Februari 2019.

Wang, C. (2011). A Longitudinal Investigation of Peer Victimization, Self-Esteem, Depression, and Anxiety among Adolescents: A Test of Cognitive Diathesis-Stress Theory, Disertation University of Nebraska.

Wiyani, N, A,. 2012. Save Our Children From School Bullying. Jogjakarta : Ar-ruzz Media. 